\title{
Consequence of the transformation of a primeval forest into a managed forest for carabid beetles (Coleoptera: Carabidae) - a case study from Bialowieża (Poland)
}

\author{
JAROSŁAW SKŁODOWSKI \\ Department of Forest Protection and Ecology, Warsaw University of Life Sciences, Nowoursynowska 159, 02-776 Warszawa, \\ Poland; e-mail: sklodowski@wl.sggw.pl
}

Key words. Coleoptera, Carabidae, species number, ecological traits, forest specialist species, long-winged, short-winged species, carabids, Białowieża primeval forest

\begin{abstract}
A comparison was made of the number of species, species diversity and ecological traits of carabid beetle (Coleoptera: Carabidae) assemblages inhabiting Białowieża Primeval Forest (National Park) and adjacent managed Białowieża forest planted following clear-cutting of the primeval forest 80 years ago. Five pitfall traps were set in each plot in the primeval and managed forests in areas that differed in terms of humidity and soil fertility. The first hypothesis tested was that the type of stand (primeval vs. managed) has a greater effect on species diversity and life history traits of carabid assemblages than soil fertility or humidity. The second hypothesis tested was that a similar hierarchy of these factors affects the occurrence of particular species. It was demonstrated that the number of species in the primeval and managed forest sites did not differ significantly, but that mesic stands within these forests were more species-rich than boggy stands. However, the Shannon index for carabids was higher for the primeval stands. More species of carabids were recorded in the boggy primeval forest than boggy managed forest. The number of species was also higher in highly fertile than less fertile stands. These results indicate that the significant differences in the patterns of ecological traits among the assemblages studied depended mainly on humidity. This indicates the managed forest that was planted where a primeval stand was clear felled 80 years ago is a good quality habitat, which is a strong argument for protecting these stands.
\end{abstract}

\section{INTRODUCTION}

Primeval forests that are untouched or only slightly affected by modern man constitute less than $1 \%$ of Europe's total forest area (Parviainen et al., 2007). European primeval forests are distinguished by a high diversity of trees and shrubs, which results in a multi-storey profile. Since dead trees are not removed, their volume can reach a very high value, 100 or even $140 \mathrm{~m}^{3}$ per hectare. Together these conditions result in a very large number of microhabitats, resulting in particularly high species diversity, eg. saproxylic beetles (Byk et al., 2006).

The Białowieża Primeval Forest $\left(1,500 \mathrm{~km}^{2}\right)$ is the only lowland forest area in temperate Europe where large tracts of natural forests, with their typical communities, still remain unaffected by man (Bobiec et al., 2000). Białowieża National Park (hereafter: the primeval forest) in the Polish part of the Białowieża Forest is protected, while the remaining forest area (hereafter: the managed forest) is still subject to exploitation for economic purposes and managed in different ways and intensities. The Białowieza forest was preserved as a royal hunting area until Word War I (1915-1918) when intensive logging began (Wesołowski \& Rowiński, 2006). When primeval forests are replaced by managed ones, the multilayer structure of the stand, composed of as many as six oak-lime-hornbeam layers (Wesołowski \& Rowiński, 2006) is simplified (Krasuska \& Miśćicki, 2002). The volume of timber (stem wood of trees over $7 \mathrm{~cm}$ in diameter) is reduced (Siitonen et al., 2000; Uotila et al., 2002), as is the number of species of trees
(Wesołowski \& Rowiński, 2006) and a drastic decrease in dead wood (Bobiec, 2002; Drozdowski, 2013) leads to a reduction in invertebrate species diversity, e.g. of saproxylic species (Byk et al., 2006).

Management alters both the structure and texture of stands; the timber volume of trees is reduced, dead wood partly "disappears" (Bobiec, 2002) and as a consequence, forest species are replaced by generalists (eg. staphlinids) and diversity of invertebrate species is reduced (Szujecki, 2006). The presence of both primeval and managed forest stands within the Białowieża forest complex provides a unique opportunity to determine the processes and patterns of the transformation of natural woodland into managed forest. One invertebrate group that has been used to study the effect of changing a primeval forest into a managed forest is epigeic ground beetles (Carabidae). Because Carabids frequently occur, are easy to capture and have a well-understood ecology, they are often used in the study of ecosystems (Schwerk \& Szyszko, 2008, 2011; Elek et al., 2010; Skalski et al., 2010, 2011; Kosewska et al., 2013; Pizzolotto et al., 2013; for a review see Lövei \& Sunderland, 1996; Niemelä et al., 2007; Koivula, 2011).

However, the occurrence of particular carabid species may depend not only on management (clear-cutting, see Szyszko, 1983; Koivula \& Niemelä, 2003, soil preparation - Skłodowski, 2014), but also on humidity and soil fertility (Thiele, 1977; Baguette, 1993; Koivula et al., 1999). But it is unknown whether humidity or soil fertility has the greater influence on the number of species, composition 
and ecological traits of carabid beetle assemblages inhabiting mature primeval and managed forests. Or perhaps of greater significance for assemblage composition and structure is the constant protection of primeval stands, rather than their transformation into managed forests. Studies on carabids and other taxa suggest that species richness in primeval stands is greater than in managed stands (Pettersson et al., 1995; Assmann, 1999; Paillet et al., 2010). Niemelä (1996) highlighted that forestry, by transforming primeval into managed forests, has caused declines in the Finnish insect fauna. It seems likely that primeval forest should support more carabid species, as well as more forest specialist species and species with low dispersal ability, than 80 -year old managed forest. Consequently carabid forest species should probably have a higher preference for primeval than for managed forest.

In this paper I study the ecological effects of changing primeval forest into managed forest and of humidity and soil fertility on carabids by comparing carabid assemblages inhabiting primeval and first-generation regenerated old managed forest, both of which are located in the same forest area. More precisely, I test the following hypotheses:

(1) The number of species, species diversity and ecological traits of carabids depends more on the type of stand (managed vs. primeval) than on soil fertility or humidity.

(2) Abundance of particular carabid species depends more on the type of stand than on soil fertility and humidity.

\section{MATERIAL AND METHODS}

\section{Study area and carabid sampling}

This study was carried out in 1999 in the primeval (Białowieża National Park - 10,517 ha) and managed Białowieża forests (Białowieża Forest District - 12,592 ha) in the Polish part of the Białowieża Forest (northern Poland: $23^{\circ} 31^{\prime}-24^{\circ} 21^{\prime} \mathrm{E}$; $52^{\circ} 29^{\prime}-52^{\circ} 57^{\prime} \mathrm{N}$ ). The Białowieża primeval forest and managed Białowieża forest are adjacent and share a common border. The Białowieża primeval forest consists of a mosaic of fertile habitats that have not been subjected to the homogenization typical of managed forests. They are multi-story, strongly diversified in terms of age and size of trees (up to 400-500 years old, reaching $55 \mathrm{~m}$ in height and $720 \mathrm{~cm}$ circumference) and species-rich (Wesołowski \& Rowiński, 2006). The managed forest stands are the first generation after the felling of the primeval stands at this site at the beginning of the $20^{\text {th }}$ century. The managed Białowieża forest is a mosaic of fragments of regenerated 80 -year old stands and younger forests planted where primeval forest previously occurred. Eighty year old forest stands were chosen for this study.

Three levels of forest soil humidity were distinguished: boggy (groundwater level reaches the surface layer of the soil, so that up to $90 \%$ of the soil surface is under water in spring), wet (groundwater level at a depth of 1-2 m, within reach of the tree roots; this is moderate humidity) and mesic (groundwater level below the tree roots, so that there is no inundation at any time of the year). In addition, three levels of forest soil fertility were distinguished: mixed coniferous (podosolic soils with acid mor humus, $\mathrm{C} / \mathrm{N}$ ratio $=25: 1$ in the litter layer and 21-22:1 in the mineral soil low soil fertility habitats with a predominance of Picea abies (L), Pinus sylvestris L. and Quercus robur L.); mixed broadleaved (brown-podosolic soil with less acid moder humus, $\mathrm{C} / \mathrm{N}$ ratio $=$ $23: 1$ in the litter layer and 19-21:1 in the mineral soil - medium soil fertility with a predominance of Quercus robur, Tilia cordata Mill., Carpinus betulus L and Picea abies); and broadleaved (brown soils with mull humus, $\mathrm{C} / \mathrm{N}$ ratio $=14-16: 1$ in the litter layer and $15: 1$ in the mineral soil - fertile and very fertile habitats with a predominance of broadleaved species: Quercus robur, Tilia cordata, Carpinus betulus and Acer platanoides L.).

Sites with each of the three levels of soil fertility were located in three areas with different levels of humidity; as a result, a total of nine sites were studied in the primeval forest and another nine in the managed forest. There were three plots in each habitat type, giving a total of 27 research plots in the primeval forest and another 27 in the managed forest ( 80 years old). The research plots were randomly distributed.

Carabids were caught in pitfall traps set at ground level in the forest. Five pitfall traps were set in each plot and inspected four times at six-week intervals, beginning on $1^{\text {st }}$ May (traps were inspected on: $1^{\text {st }}$ May, $15^{\text {th }}$ June, $1^{\text {st }}$ August and $30^{\text {th }}$ October). The research lasted 180 days. A total of $270(27 * 5+27 * 5)$ pitfall traps were changed during each of the 4 inspections. The traps $(0.51$ glass jars with a plastic funnel, $12 \mathrm{~cm}$ in diameter, containing 100 $\mathrm{ml} \mathrm{70 \%} \mathrm{ethylene} \mathrm{glycol)} \mathrm{were} \mathrm{arranged} 15 \mathrm{~m}$ apart along transects. Data from the 5 traps set in each plot were pooled.

\section{Ecological traits of carabids}

For the purposes of the present analysis, carabid species were divided into groups according to two different criteria. The first of these was dispersal power, and the categories were short-winged species, wing-polymorphic species and species with the highest dispersal potential, i.e. long-winged species. Particularly in forests, short-winged carabids have the lowest dispersal power, which makes it difficult for them to re-colonize forests after a disturbance. All of these types were distinguished based on wing length and wing muscles and information in the literature (Turin, 2000).

The second classification of carabid beetles was based on their habitat preferences. The groups identified were forest specialist species (species associated with closed canopy and mature trees), generalists (present both in forests and open areas) and open-area species. The species were classified based on observations by the author, Burakowski et al. $(1973,1974)$ and Szyszko (1983).

\section{Data analysis}

Number of species was standardized to the lowest number of specimens in the samples using Simberloff's rarefraction formula, corrected by Hurlbert (Krebs \& Kenney, 2011). In order to characterize more comprehensively the species diversity of each carabid community, the Shannon diversity index $(\mathrm{H})$ was calculated (bias corrected according to Chao \& Shen, 2003 and calculated using software of Colwell, 2013).

The distribution of the empirical data was tested for normality using the Shapiro-Wilk test. Data with a normal distribution were analyzed using three-way Analysis of Variance. A post hoc comparison of significant differences in the ANOVA was performed using Scheffe's test (StatSoft Inc., 2011). In all cases in which the distribution of the empirical data was not normal, data were tested using a General Linear Model (with a log link function). For each index, the dependency of the percentage of particular species groups on the following factors was determined: soil fertility (Fertility: mixed coniferous "MC", mixed broadleaved "MBL" and broadleaved "BL"); habitat humidity (Humidity: boggy "b", wet "w" and mesic "m"); type of forest stand (Forest: primeval, managed) and the interactions between these factors.

The first hypothesis was tested in two steps. In step 1, indirect ordination of the ground beetle assemblages inhabiting different sites in the primeval and managed forests was performed using 


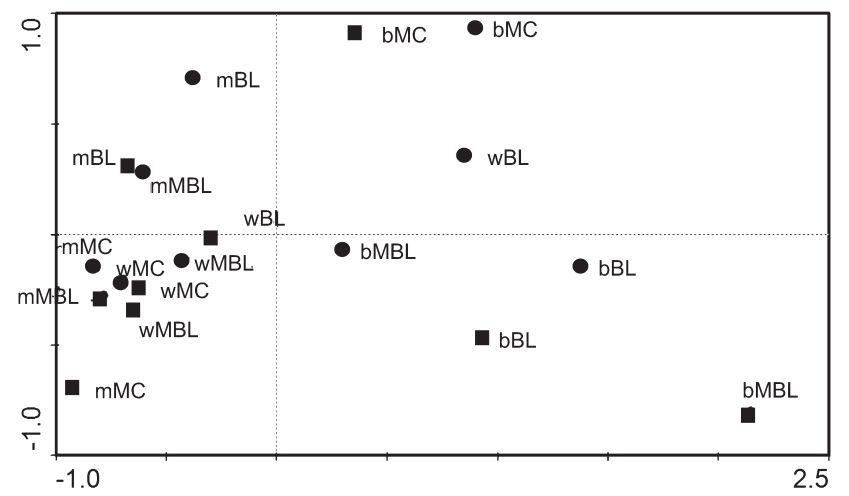

Fig. 1. Non-metric multidimensional scaling analysis (NMDS) ordination of carabid assemblages inhabiting primeval (squares) and managed forests (circles) (NMDS stress $=0.10$; ANOSIM: $\mathrm{R}$ $=0.03, \mathrm{p}=0.24)$. Abbreviations of habitat names: $\mathrm{b}-$ boggy, $\mathrm{w}$ - wet, $\mathrm{m}$ - mesic, MC - mixed coniferous, MBL - mixed broadleaved and $\mathrm{BL}$ - broadleaved habitats.

non-metric multidimensional scaling, calculated in WinKyst 1.0 (Šmilauer, 2002; Lepš \& Šmilauer, 2003) on a Bray-Curtis similarity matrix, which was visulized in a PCA diagram in the Canoco 4,5 package. The most important environmental factor, type of forest (primeval or managed forest), habitat humidity, or soil fertility, was determined using Redundancy Analysis RDA and then a Generalized Linear Model was performed in the CANODRAW module. The most suitable model was inferred using Akaike's information criteria (AIC), based on model fit (Johnson \& Omland, 2004).

The significance of multivariate differences between carabid assemblages classified according to the type of stand they inhabit (primeval or managed) or the type of habitat (in terms of humidity and soil fertility) was tested using one-way analysis of similarity (ANOSIM) (Clarke, 1993). In step 2, the first hypothesis was investigated by comparing the mean number of species and the Shannon diversity index $(\mathrm{H})$ for the primeval and managed forests and the different soil fertility and humidity habitats, which was verified using three-way analysis of variance. Selected ecological traits of the carabid assemblages were compared at different levels of soil fertility, humidity and forest exploitation. In this analysis, the proportion of particular groups, as defined above in the section "Ecological traits of carabids", based on dispersal potential and habitat preference, was tested using GLM (Poisson distribution).

The second hypothesis was tested by determining whether the occurrence of the most numerous carabid species (minimum of 500 individuals caught) was correlated with habitat humidity, soil fertility and type of stand using linearized nonlinear regression. (StatSoft Inc., 2011).

\section{RESULTS}

\section{Species richness of carabid assemblages}

A total of 23,906 carabids belonging to 79 species were caught $(12,657$ belonging to 72 species were caught in the primeval stands, and 11,249 to 65 species in the managed stands). There were 17 carabid species - mainly non-forest species - caught in the managed stands that were not found in the primeval stands, while only 14 species were caught in the primeval stands that were not caught in the managed stands. A non-metric multidimensional scaling performed using a Bray-Curtis similarity matrix of the carabid assemblages indicated that the assemblages had a close association with the first two dimensions (final stress $=0.10$; Fig. 1). The first axis, which accounted for $76.7 \%$ of the total variance, clearly separated assemblages inhabiting boggy forest habitats (right side of the diagram) from wet and moist forest habitats (left side). The GLM indicated a strong association between habitat humidity and the first ordination axis $(\mathrm{F}=18.21 ; \mathrm{p}>0.001 ; \mathrm{AIC}=11.076)$, while the type of stand (primeval or managed) was associated with the second axis, with borderline significance ( $\mathrm{F}=$ $3.51 ; \mathrm{p}=0.080 ; \mathrm{AIC}=20.278)$. ANOSIM tests confirmed that ground beetle assemblages from boggy habitats dif-

TABLE 1. The results of the ANOVA of the number of carabid species and bias-corrected Shannon indices. Scheffe' post-hoc test was performed. Humidity gradient: $\mathrm{b}$ - boggy, $\mathrm{w}-$ wet, $\mathrm{m}$ - mesic habitats. Fertility gradient: $\mathrm{MC}$ - mixed coniferous forests, MBL - mixed broadleaved forests, BL - broadleaved forests. Level of significance: $* 0.01 ; * *<0.001$.

\begin{tabular}{|c|c|c|c|c|c|}
\hline Variable & SS & $\mathrm{df}$ & MS & $\mathrm{F}$ & Post hoc \\
\hline \multicolumn{6}{|l|}{ Species number } \\
\hline Intercept & 8072.770 & 1 & 8072.779 & $1964.928 * *$ & \multirow{6}{*}{$\begin{array}{c}\mathrm{BL}>* * \mathrm{MBL}, \mathrm{MC} \\
\mathrm{m}, \mathrm{w}>* * \mathrm{~b}\end{array}$} \\
\hline Fertility & 119.930 & 2 & 59.967 & $14.596^{* *}$ & \\
\hline Humidity & 222.850 & 2 & 111.427 & $27.122 * *$ & \\
\hline Forest & 0.952 & 1 & 0.952 & 0.232 & \\
\hline Fertility * Humidity & 18.695 & 4 & 4.674 & 1.138 & \\
\hline Forest $*$ Fertility & 22.227 & 2 & 11.114 & 2.705 & \\
\hline Forest $*$ Humidity & 73.908 & 2 & 36.954 & $8.995 * *$ & \multirow[t]{3}{*}{ primeval $b>*$ managed $b$} \\
\hline Forest $*$ Fertility $*$ Humidity & 18.091 & 4 & 4.523 & 1.101 & \\
\hline Error & 147.904 & 36 & 4.108 & & \\
\hline \multicolumn{6}{|l|}{ Shannon $(H)$ index } \\
\hline Intercept & 281.079 & 1 & 281.079 & $271040.000 * *$ & \multirow{9}{*}{$\begin{array}{c}\mathrm{BL}, \mathrm{MBL}>* * \mathrm{MC} \\
\mathrm{m}, \mathrm{w}>* \mathrm{~b} \\
\text { primeval }>* * \text { managed }\end{array}$} \\
\hline Fertility & 0.059 & 2 & 0.023 & $28.609 * *$ & \\
\hline Humidity & 0.017 & 2 & 0.008 & $7.963^{*}$ & \\
\hline Forest & 0.054 & 1 & 0.054 & $51.607 * *$ & \\
\hline Fertility * Humidity & 0.028 & 4 & 0.007 & $6.645^{* *}$ & \\
\hline Forest $*$ Fertility & 0.044 & 2 & 0.022 & $21.055^{* *}$ & \\
\hline Forest $*$ Humidity & 0.018 & 2 & 0.009 & $8.787 * *$ & \\
\hline Forest $*$ Fertility $*$ Humidity & 0.026 & 4 & 0.006 & $6.152 * *$ & \\
\hline Error & 0.037 & 36 & 0.001 & & \\
\hline
\end{tabular}


a

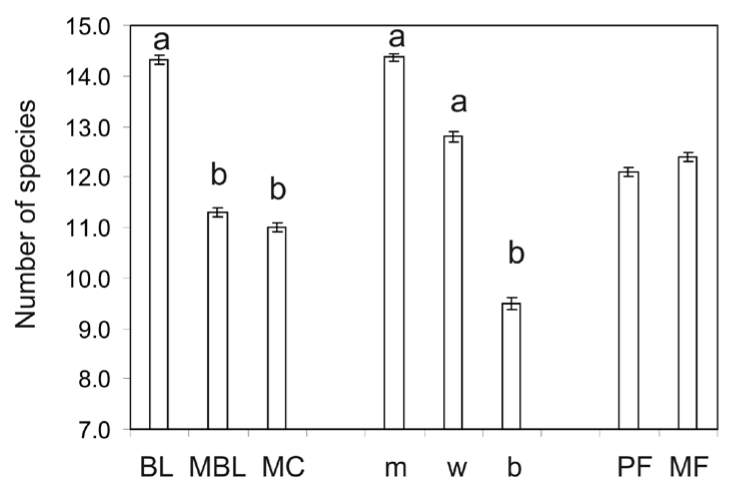

b

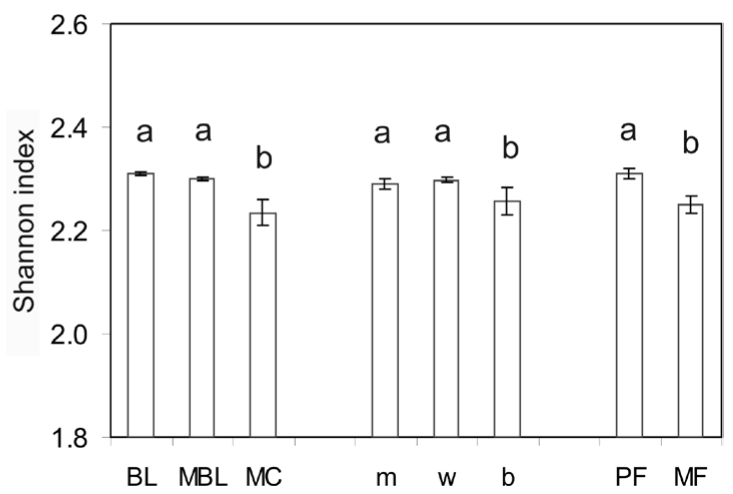

Fig. 2. Number of species (a), Shannon index $(b)(m e a n \pm S E)$. Different letters indicate significant differences (Scheffe's post hoc test; $\mathrm{p}<0.05)$. Abbreviations of habitat names: $\mathrm{b}$ - boggy, $\mathrm{w}$ - wet, $\mathrm{m}-$ mesic, $\mathrm{MC}$ - mixed coniferous, $\mathrm{MBL}-$ mixed broadleaved and $\mathrm{BL}$ - broadleaved habitats, $\mathrm{PF}$ - primeval forest, $\mathrm{MF}$ - managed forest.

TABLE 2. The results of the GLM of ecological traits of carabids. Scheffe' post-hoc test was performed. Humidity gradient: $b$ - boggy, $\mathrm{w}$ - wet, $\mathrm{m}$ - mesic habitats. Fertility gradient: MC - mixed coniferous forests, BLM - mixed broadleaved forests, BL - broadleaved forests. Level of significance: * $0.05 ; * * 0.01 ; * * * 0.005 ; * * * *<0.001$

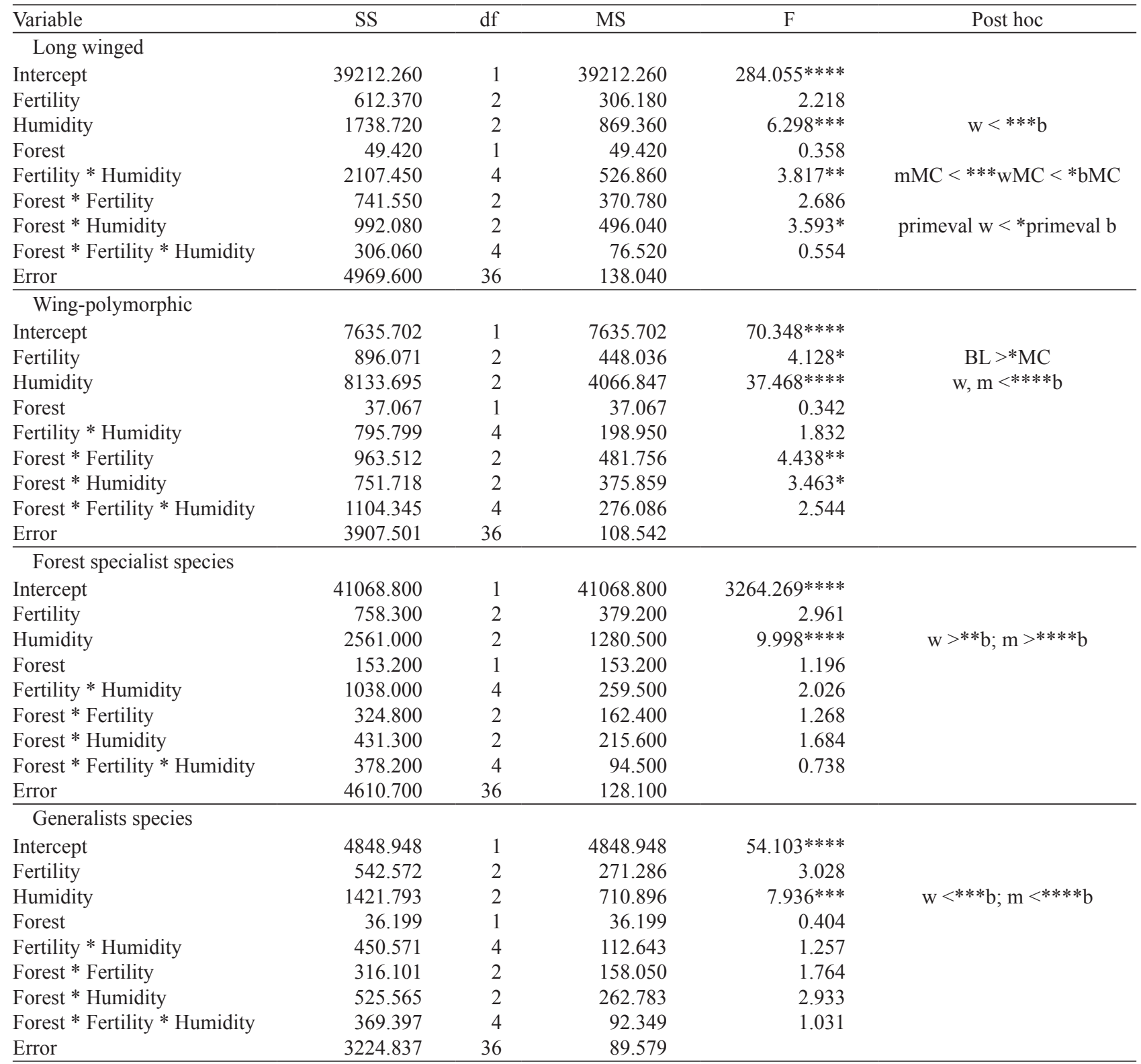


a

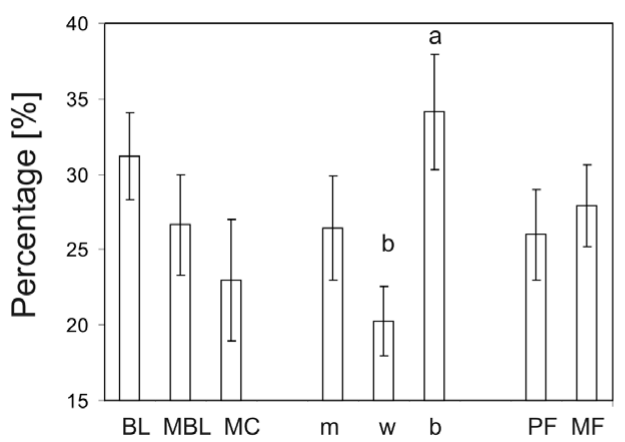

C

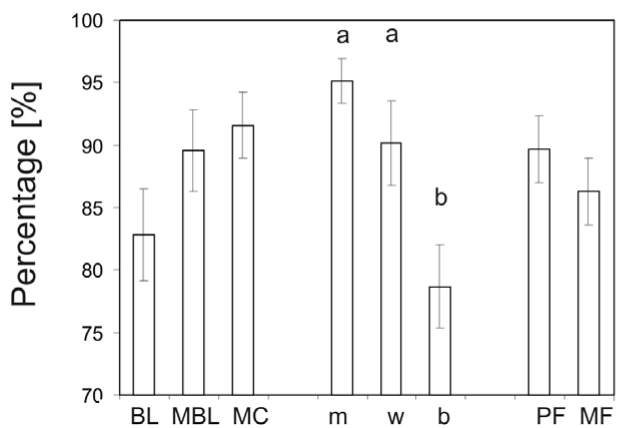

b

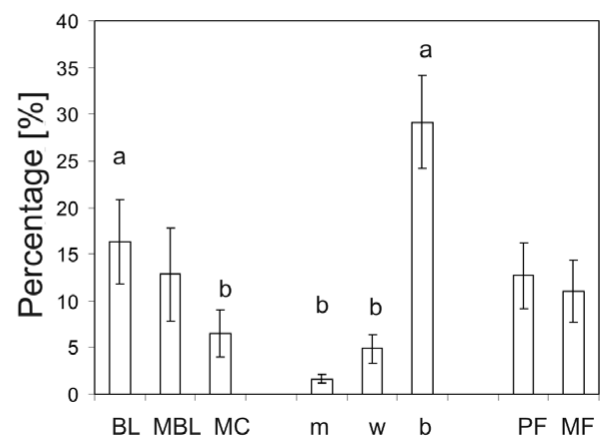

d

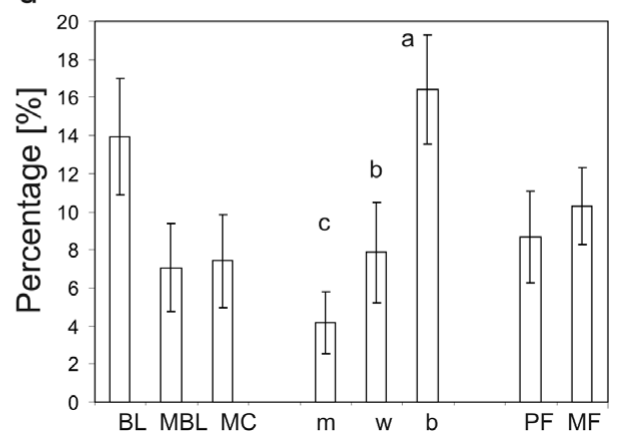

Fig. 3. Percentage of long-winged (a), wing-polymorphic (b), forest (c), generalists species (d) (mean $\pm \mathrm{SE}$ ). Abbreviations of habitat names: $\mathrm{b}$ - boggy, $\mathrm{w}$ - wet, $\mathrm{m}$ - mesic, $\mathrm{MC}$ - mixed coniferous, $\mathrm{MBL}$ - mixed broadleaved and $\mathrm{BL}$ - broadleaved habitats, PF - primeval forest, $\mathrm{MF}$ - managed forest.

fered significantly from those recorded in wet (ANOSIM $\mathrm{R}=0.54, \mathrm{p}=0.008$ ) and mesic habitats (ANOSIM $\mathrm{R}=$ $0.73, \mathrm{p}=0.002)$.

The ANOVA analysis did not reveal any significant differences between the primeval and managed forests in the mean number of carabid species captured, but that the values of the Shannon indices differed (Table 1, Fig. 2). In general, the number of carabid species (rarefied) and the Shannon index values recorded for fertile broadleaved forests were greater than those recorded for mixed coniferous forests (Table 1, Fig. 2). The highest number of species and highest Shannon index were recorded for the mesic habitats and the lowest for boggy habitats (Table 1, Fig. 2).

\section{Ecological traits of carabids in relation to soil fertility and humidity}

GLM most often indicated differences in the structure of carabid assemblages inhabiting tree stands growing in environments with different levels of humidity (Table 2, Fig.
3). Only in the case of wing-polymorphic species did GLM indicate a significantly higher percentage in assemblages present in the fertile broadleaved habitat. In general, the percentage of long winged, wing-polymorphic and generalist species in the assemblages increased with habitat humidity, while the percentage of forest specialist species decreased.

\section{Occurrence of the different species of carabids in the different forest habitats}

Carabid abundance was negatively correlated with habitat humidity in the nonlinear regression analysis, except for Carabus hortensis L. whose abundance was positively correlated (Table 3). Weaker correlations were recorded for soil fertility (Cychrus caraboides L., Pterostichus niger Schaller and Pterostichus oblongopunctatus Fabricius) and type of forest (Carabus glabratus Paykull and Carabus nemoralis Muller).

TABLE. 3. Linearized nonlinear regression of the abundance of selected species of carabids in habitats differing in level of humidity (Humidity), fertility (Fertility) and type of forest primeval forest transformed into managed forest (Managed).

\begin{tabular}{|c|c|c|c|c|c|c|c|}
\hline \multirow{2}{*}{ Species } & \multirow[t]{2}{*}{ R2 } & \multicolumn{2}{|l|}{ Humidity } & \multicolumn{2}{|c|}{ Fertility } & \multicolumn{2}{|c|}{ Managed } \\
\hline & & B & $\mathrm{p}$ & $\mathrm{B}$ & $\mathrm{p}$ & $\mathrm{B}$ & $\mathrm{p}$ \\
\hline Carabus arvensis & 0.28 & $-0.51 \pm 0.12$ & $<0.001$ & - & - & - & - \\
\hline C. glabratus & 0.48 & $-0.55 \pm 0.10$ & $<0.001$ & - & - & $-0.41 \pm 0.10$ & $<0.001$ \\
\hline C. hortensis & 0.38 & $0.59 \pm 0.11$ & $<0.001$ & - & - & - & - \\
\hline C. nemoralis & 0.27 & $-0.32 \pm 0.12$ & 0.009 & - & - & $0.33 \pm 0.12$ & 0.008 \\
\hline Cychrus caraboides & 0.39 & $-0.58 \pm 0.11$ & $<0.001$ & $0.23 \pm 0.11$ & 0.04 & - & - \\
\hline Pterostichus niger & 0.26 & $-0.41 \pm 0.12$ & 0.001 & $0.28 \pm 0.12$ & 0.02 & - & - \\
\hline P. oblongopunctatus & 0.42 & $-0.61 \pm 0.11$ & $<0.001$ & $0.22 \pm 0.11$ & 0.04 & - & - \\
\hline
\end{tabular}




\section{DISCUSSION}

\section{Species richness of carabid assemblages}

In comparison with managed forests the species richness of carabids in unmanaged forests can be higher (Niemelä, 1996; Assmann, 1999; Paillet et al., 2010), lower (Magura et al., 2003) or equal (Magura et al., 2000). Unmanaged European forests support a higher species diversity than managed forests, not only of carabids but also of bryophytes, lichens, fungi and saproxylic beetles (Paillet et al., 2010). The Shannon index was higher for assemblages of carabids inhabiting the primeval forest than the managed forest, while the number of species recorded in both types of stand was similar. There may be several reasons for the higher Shannon index for carabid species in the primeval forest.

Firstly, at the tree level, microhabitat heterogeneity was not influenced by forest management but only by tree characteristics, with more microhabitats associated with large trees and snags (Vuidot et al., 2011). The larger the basal area, which is strongly correlated with the DBH of trees, the greater the species richness (Toïgo et al., 2013). In the Białowieża primeval stands, however, due to natural processes associated with the regeneration of tree stands there are more trees with a large DBH there than in the managed forest (Bobiec et al., 2000). The availability of microhabitats in managed forests is below the levels required by many species, whereas natural closed-canopy stands of all ages exceed this threshold level (Hansen et al., 1991). For all of these reasons the presence of large trees in the primeval forest is associated with high species diversity.

Secondly, a possible factor increasing microhabitat diversity in the primeval forests are small patches that result from gap dynamics evoked by both biotic and abiotic factors (Picket \& White, 1985). The utilization of forest practiced in managed forests, however, leads to heterogenization of stands on a broader scale; there are young stands adjacent to the old ones. This leads to strong differences in light conditions in managed forests. Species with different ecological requirements, such as open land and forest specialist species, may be favoured by heterogeneous light conditions (Toïgo et al., 2013). A heterogeneous habitat may have a greater species richness than a homogeneous one (MacArthur, 1965; Pettersson et al., 1995; Niemelä et al., 1996). It is possible that the large number of carabid species associated with the more microhabitats in primeval forests is partly compensated for by the greater number of species occurring in managed forests because of the greater diversity of light conditions in the stands bordering on young stands. This seems to be the reason for the lack of a difference in the number of species.

There is a general dependence of the number of species of carabids on the depth and quality of forest litter (Koivula et al., 1999). Forest litter in the primeval forest has remained untouched, while in the managed forests it was partly regenerated after tree cutting and soil preparation 80 years earlier. It is likely that different carabid species inhabit different layers within leaf litter (Thiele, 1977). Moreover, dead wood (Pearce et al., 2003; Skłodowski,
2003, Fuller at al., 2008) favours an increase in the number of carabid species in primeval forests. There are species of carabids living in decaying trees and tree holes even 2 $\mathrm{m}$ above ground (Skłodowski, 2003). There are more tree holes in natural forests than in managed forests (Vouidot et al., 2011). For this reason, both the number of species and the number of individuals in the primeval forest were higher than in the managed forests, which might have increased the species diversity. On the other hand, forest management practices can result in an increase in the number of species; clear-cutting, even of small areas, increases species richness above the level recorded in a primeval coniferous forest (Niemelä et al., 1988) or even an old managed forest (Szyszko, 1983, Beaudry, 1997; Koivula \& Niemelä, 2003; du Bus de Warnaffe \& Lebrun, 2004).

This is only one of a few possible explanations of the results of this research, because the factors affecting assemblage structure in these two habitats are likely to be more complex than heterogeneity of canopy structure and the dependent light levels. Stenotopic species, which are dependent on microhabitats only present in primeval forests, should also be taken into account. In the primeval forests three such stenotopic species were found: Badister unipustulatus, Carabus intricatus and Leistus ferrugineus. A particularly important stenotopic species is C. intricatus, which in Poland inhabits only old stands with decaying wood. The lack of $C$. intricatus in managed forests seems to indicate a lack of decaying wood in such stands. Another species, L. ferrugineus, which occurred only in primeval forests, hunts springtails in the upper levels of the litter layer. Its absence in the managed forests may suggest an impoverished litter layer in this stand. However, the occurrence of certain species in both primeval and managed forests may indicate similar living conditions for carabids in both types of stand. One such species is Leistus piceus, which occurs in Poland in the mountains and in lowlands only in the Białowieża forest. It hunts springtails in the litter layer. The presence of this species in the managed forest, despite the lack of decaying wood, suggests the presence of other unrecognized microhabitats that were not destroyed by clear felling.

Ordination indicates that there is a clear distinction between the assemblages recorded in habitats with different levels of humidity and to some extent those with different soil fertility, but not those in the different types of forest (primeval or managed). The number of carabid species seems to be more dependent on humidity than soil fertility of the forest stands or on the type of forest (primeval or managed). In the managed forest, the boggiest habitats are flooded in spring, resulting in a small number of microhabitats and a lower number of species in comparison with the most mesic habitats. In the primeval forest there are more microhabitats in the boggiest habitats than in the boggy areas in the managed forest, due mainly to the high number of old trees with high $\mathrm{DBH}$, which increases microhabitat diversity above the level recorded in the managed forest. Only in the boggy habitats was the number of carabid species inhabiting the primeval forests statistically significant- 
ly higher than in managed forests, which demonstrates the particularly high value of the boggy areas in the primeval forest (there were 7 species in the primeval forest that were not recorded in the managed forest: Agonum gracilis, A. micans, A. sexpunctatum, Badister unipustulatus, Leistus rufomarginatus, L. piceus, L. terminatus). The importance of boggy areas in primeval forests is also indicated by the substantially greater number of species of spider in them than in managed forests (Stańska et al., 2002).

In broadleaved habitats there were more carabid species than in mixed broadleaved and mixed coniferous habitats, which is consistent with the reports of Fahy \& Gormally (1998), Magura et al. (2002), Fuller et al. (2008) and Nietupski et al. (2008). The greater number of species of carabids in fertile habitats probably results from the greater diversity of available prey there than in less fertile habitats (such as springtails, dung beetles and spiders - Szujecki, 2001). In broadleaved habitats humus is characterized by low acidification and high diversity of invertebrate species (the mul type of humus) but in mixed broadleaved and especially in mixed coniferous habitats humus is more acidic and the diversity of invertebrate species is lower, which decreases the availability of prey for carabids. Toïgo et al. (2013) also report a lower species richness in more acidified humus than less acidic humus.

\section{Ecological traits of carabid assemblages associated with differences in soil fertility and humidity of forest sites}

I expected more forest specialist species in the primeval forest because of its multi-story structure and undisturbed soil profile. After a primeval stand is cut down, soil plowing before reforestation causes a strong disturbance, due to the considerable changes not only in the soil but also in the litter layer. The deeper the plowing the greater the changes recorded in carabid assemblages (Sklodowski, 2014). Late successional species, e.g. Carabus violaceus, Pterostichus niger and Notiophilus biguttatus, prefer minimum tillage and avoid plowed soil (Holland \& Luff, 2000). The various effects of plowing on carabids has been reviewed by Kromp (1999) and Holland \& Luff (2000). Full regeneration of carabid beetle assemblages after clear-cutting, soil plowing and reforestation can take 30-60 years (Szujecki et al., 1983). Thus plowing the soil in the managed stands may have led to changes in carabid assemblages. The thicker the litter layer the greater the level of humidity in this habitat and the number of microhabitats, thus enabling the co-occurrence of species with different habitat preferences (Koivula et al., 1999), which results in an increase in the number of carabid forest specialist species (Koivula et al., 1999; Magura et al., 2002, Niemelä et al., 2007; Fuller et al., 2008). Moreover, large volumes of dead wood (in primeval forests) increase the number of microhabitats for carabids and the number of their prey (Bengtsson et al., 1998; Pearce et al., 2003; Bouget \& Duelli, 2004; Bouget, 2005; Latty et al., 2006; Fuller et al., 2008). Toïgo et al. (2013) found that the diversity of forest species increased with the basal area of trees, which is strongly correlated with tree volume. Bobiec (2002) found an approximately two-fold larger volume of trees in the primeval forest in Białowieża (from 336 to $555 \mathrm{~m}^{3} \mathrm{ha}^{-1}$ ) than in the commercial forest $\left(239-279 \mathrm{~m}^{3} \mathrm{ha}^{-1}\right)$. For these reasons, the percentage of forest specialist species should be higher in the primeval forest than in the managed forest. The share of forest species was higher in the primeval forest than in the managed forest, but the difference was not significant and the percentage share of forest species in the two types of forest should be considered equal.

The equal share of forest specialist species in the carabid assemblages inhabiting the primeval and managed forest (after cutting of primeval stands) seems to indicate that the environmental conditions in the two habitats may be similar. Toïgo et al. (2013) found a positive dependence between the number of forest species and the time for which a forest had not been managed (no trees had been harvested for at least 15 years). On the other hand there are more authors who have demonstrated strong dependence of forest species on the management practice, e.g. decrease in the proportion of forest species and increase in open land species (Szyszko 1983; Beaudry et al., 1997; Koivula \& Niemelä, 2003; Niemelä et al., 2007).

The percentage of forest specialists was smaller in the periodically flooded boggy stands than in the drier stands. According to Kwiatkowski (2011), habitat generalists reach their maximum percentages in boggy stands, hence clear cutting of wet and boggy forest habitats does not cause a strong degradation of the carabid fauna. Boggy stands are usually characterized by a higher degree of canopy opening than wet and mesic stands, because in boggy stands trees are more easily felled by wind, which creates gaps in the stands.

In more open stands conditions are more favourable for habitat generalists than for stenotopic species.

My findings show a similar pattern, perhaps because boggy stands (due to downing of some trees by wind) usually have a higher degree of canopy opening than drier (wet and mesic) stands, which increases the percentage of generalists and open habitat species (du Bus de Warnaffe \& Lebrun, 2004; Fernández \& Saldago Costas, 2004; Bouget, 2005; Elek et al., 2005; Skłodowski \& Garbalińska, 2011).

Carabid assemblages in the bogs I sampled that were periodically flooded, were dominated by species with potentially good dispersal power, i.e. long-winged and wing polymorphic species, while short-winged species dominated at drier sites. Winged species, with a higher dispersal potential, efficiently colonize disturbed ecosystems (den Boer, 1970; Skalski \& Pospiech, 2006), entering clear cut area even months after the disturbance (Koivula, 2002; Koivula \& Niemelä, 2003). After the decrease in the water table that resulted from the melting of the snow cover in late spring, long-winged species (with high dispersal power) colonized boggy forests more rapidly than shortwinged species (with poor dispersal power). Short-winged species are associated with mesic habitats in which the basal area of trees is greater than in boggy habitats. Toïgo et al. (2013) report that the diversity of this kind of species increased with basal area of the trees. Long-winged and wing 
polymorphic species are best able to colonize temporarily flooded boggy stands, while short-winged species prefer the driest (mesic) forest stands. The ecological traits associated with carabid assemblages recorded in forest habitats seem to depend to a far greater degree on their humidity than soil fertility.

\section{Occurrence of particular species of carabids in different forest habitats}

Boggy habitats are less favourable than mesic ones for $C$. arvensis, $C$. glabratus, $C$. nemoralis, $C$. caraboides, $P$. niger and $P$. oblongopunctatus, probably because the litter and humus layer in these forests are shallower. The abundance of forest specialist species increases with increase in the depth of litter (Baguette, 1993; Koivula et al., 1999). Only the abundance of $C$. hortensis was positively correlated with the humidity of forest habitats. This is probably due to the well-developed moss layer in boggy habitats, because $C$. hortensis prefers the moss layer (Heliölä et al., 2001). On other hand, the abundance of only three species (C. caraboides, $P$. niger and $P$. oblongopunctatus) was weakly correlated with soil fertility. These results also indicate that humidity has a greater effect than soil fertility on carabids in primeval and old managed forests.

C. glabratus was more abundant in primeval stands. This is a late successional species preferring old forests in Central Europe (Turin et al., 2003) and in Germany is restricted to forests that have existed continuously since 1800 (Assmann, 1999). Disappearance of forest litter together with the moss layer eliminates C. glabratus (Skłodowski \& Garbalinska, 2011). This species is sensitive to clear cutting and soil preparation, after which it quickly disappears from the plowed area, and slowly recolonizes it after a few years (Skłodowski, 2008). Preference of C. glabratus for primeval stands is probably connected with the presence of undisturbed layers of mosses, soil and forest litter. In managed stands, forest litter and the moss layer are partly destroyed due to preparation of the soil for reforestation, which is associated with a reduction in the abundance of C. glabratus, whereas $C$. nemoralis was more abundant in managed stands, owing to its preference for transformed environments, i.e., scrub, gardens, hedgerows, forest edges and all kinds of forest (Turin et al., 2000) and the fact that it is a habitat generalist (Toïgo et al., 2013).

In conclusion, it is proposed that three species could be used more widely for monitoring primeval forests in Europe. C. glabratus seems to be an especially important indicator species of primeval stands and $C$. nemoralis of managed stands. Another species, C. hortensis, seems to be an indicator species of well preserved boggy and wet stands. The hypothesis that there is higher number of species of carabids in primeval stands than in managed stands in the Białowieża forest was only confirmed in the case of boggy stands. This is an important finding and a strong argument for the conservation of boggy habitats in forests.

The effect of habitat humidity and to a lesser extent soil fertility, on species diversity and ecological traits of carabid assemblages (especially the percentage of forest specialist species) in forests is an important factor affecting the management and protection of ecosystems. It indicates that boggy stands should be strongly protected. Also, the similar number of species of ground beetles and percentage of forest specialist species in primeval and managed stands may suggest that the condition of managed forests planted where previously there were primeval stands is good and indicates the economic exploitation of these stands should be limited. In the managed forest the best form management is the removal of single trees rather than clear felling, which results in the harvesting of only a few trees from time to time, leaving all other trees untouched. The method of extracting the logs is also important: extraction of harvested wood should be carried out using a forwarder, which carries logs clear of the ground and does not damage the soil profile. This makes it possible to minimize the destruction of microhabitats in the litter layer as well in decaying wood. Moreover, particular attention should be paid to boggy stands, which are extraordinarily valuable. All such stands should be strictly protected. If this is not possible, further exploitation of such managed forests should be conducted so as to have the least possible effect on the ecosystem by restricting tree felling to very small areas.

ACKNOWLEDGEMENTS. I would like to express my heartfelt thanks to A. Szujecki, the leader of this research project. My thanks also due to my colleagues for their assistance with field work. I also wish to thank S. Wild for her help with the English translation of the text, and two anonymous reviewers for their valuable comments, which resulted in significant improvements in this article.

\section{REFERENCES}

Assmann T. 1999: The ground beetle fauna of ancient and recent woodlands in the lowlands of north-west Germany (Coleoptera, Carabidae). - Biodivers. Conserv. 8: 1499-1517.

BAGUETTE M. 1993: Habitat selection of carabid beetle in deciduous woodlands of southern Belgium. - Pedobiologia 37: 365-378.

Beaudry S., Duchesne L.C. \& Côté B. 1997: Short term effects of three forestry practices on carabid assemblages in a jack pine forest. - Can. J. Res. 27: 2065-2071.

Bengtsson J., Lundkvist H., Saetre P., Sohlenius B. \& Solbreck B. 1998: Effects of organic matter removal on the soil food web: forestry practices meet ecological theory. - Appl. Soil Ecol. 9: 137-143.

BobIEC A. 2002: Living stands and dead wood in the Białowieża forest: suggestions for restoration management. - Forest Ecol. Manag. 165: 125-140.

Bobiec A., Burt H., Meijr K., Zuyderduyn C., Haga J. \& VlaanDEREN B. 2000: Rich deciduous forest in Białowieża as a dynamic mosaic of developmental phases: premises for nature conservation and restoration management. - Forest Ecol. Manag. 130: 159-175.

Bouget C. 2005: Short-term effect of windthrow disturbance on ground beetle communities: gap and gap size effects. In Lövei G. \& Toft S. (eds): European Carabidology 2003: Proceedings of the 11th European Carabidologists' Meeting, Aarhus (DK). Danish Institute of Agricultural Sciences report, no. 114, pp. 25-40.

Bouget C. \& Duelli P. 2004: The effect of windthrow on forest insect communities: a literature review. - Biol. Conserv. 118: 281-299. 
Burakowski B., Mroczkowski M., Stefańska J. 1973: Katalog Fauny Polski, Chrzaszcze, Coleoptera, Biegaczowate, Carabidae. [Catalogue of Fauna of Poland, Beetles, Coleoptera, Ground Beetles, Carabidae.] Vol. XXIII, Tom 2. Part 1. PWN, Warszawa, 233 pp. [in Polish].

Burakowski B., Mroczkowski M., Stefańska J. 1974: Katalog Fauny Polski, Chrzaszcze, Coleoptera, Biegaczowate, Carabidae. Vol. XXIII, Tom 3. Part 2. PWN, Warszawa, 430 pp. [in Polish].

Byk A., Mokrzycki T., Perliński S. \& Rutkiewicz A. 2006: Saproxylic beetles - in the monitoring of anthropogenic transformation of Białowieża Primeval Forest. In A. Szujecki (ed.): Zooindication-based of Anthropogenic Transformations in Białowieża Primeval Forest. Warsaw Agricultural University Press, Warszawa, pp. 325-397.

Clarke K.R. 1993: Non-parametric multivariate analysis changes in community structure. - Aust. J. Ecol. 18: 117-143.

Colwell R.K. 2013: EstimateS: Statistical Estimation of Species Richness and Shared Species from Samples. Version 9. Persistent URL < purl.oclc.org/estimates>.

DEN BOER PJ. 1970: On the significance of dispersal power for populations of Carabid beetles (Coleoptera, Carabidae). - Oecologia 4: 1-28.

DrozDowsKi S. 2013: Modelowanie procesów odnowieniowych $w$ lesie naturalnym. [Modeling of Regeneration Processes in Natural Forest.] SGGW, Warszawa, 139 pp. [in Polish, English abstr.].

Du Bus de Warnaffe G. \& Lebrun P. 2004: Effects of forest management on carabid beetles in Belgium: implications for biodiversity conservation. - Biol. Conserv. 118: 219-234.

Elek Z., Magura T. \& TóthMÉrész B. 2005: Effect of canopy closure of a young Norway spruce plantation on ground beetles. In Lövei G. \& Toft S. (eds): European Carabidology 2003: Proceedings of the 11th European Carabidologists' Meeting, Aarhus (DK). Danish Institute of Agricultural Sciences report, no. 114 , pp. 89-97.

Elek Z., Dauffy-Richard E. \& Gosselin F. 2010: Carabid species responses to hybrid poplar plantations in floodplains in France. - Forest Ecol. Manag. 260: 1446-1455.

FAHY O. \& GoRmally M. 1998: A comparison of plant and carabid communities in an Irish oak woodland with a nearby conifer plantation and clearfelled site. - Forest Ecol. Manag. 110: $263-273$.

Fernández Fernández M.M. \& Salgado Costas J.M. 2004: Recolonization of a burnt pine forest (Pinus pinaster) by Carabidae (Coleoptera). — Eur. J. Soil Biol. 40: 47-53.

Fuller R.J., Oliver T.H. \& Leather S.R. 2008: Forest management effects on carabid beetle communities in coniferous and broadleaved forests: implications for conservation. - Insect Conserv. Diver. 1: 242-252.

Hansen A.J., Spies T.A., Swanson F.J. \& Ohmann J.L. 1991: Conserving biodiversity in managed forests - Lessons from natural forests. - BioScience 41: 382-392.

Heliölä J., Koivula M. \& Niemelä J. 2001: Distribution of carabid beetles (Coleoptera, Carabidae) across a boreal forestclearcut ecotone. - Conserv. Biol. 15: 370-377.

Holland J.M. \& Luff M.L. 2000: The effects of agricultural practices on Carabidae in temperate agroecosystems. - Integr. Pest Manag. Rev. 5: 109-129.

Johnson J.B. \& OMLAND K.S. 2004: Model selection in ecology and evolution. - Trends Ecol. Evol. 19: 101-108.

KoIvula M. 2002: Alternative harvesting methods and boreal carabid beetles (Coleoptera, Carabidae). — Forest Ecol. Manag. 167: $103-121$.
Korvula M. 2011: Useful model organisms, indicators, or both? Ground beetles (Coloptera, Carabidae) reflecting environmental conditions. - ZooKeys 100: 287-317.

KorvUla M. \& NiEMELÄ J. 2003: Gap felling as a forest harvesting method in boreal forests: responses of carabid beetles (Coleoptera, Carabidae). - Ecography 26: 179-187.

Koivula M., Punttila P., Haila Y. \& Niemalä J. 1999: Leaf litter and the small scale distribution of carabid beetles (Coleoptera, Carabidae) in boreal forest. - Ecography 22: 424-435.

Kosewska A., Nietupski M. \& Damszel M. 2013: Role of urban forests as a source of diversity of carabids (Coleoptera: Carabidae) in urbanised areas. - Baltic J. Coleopt. 13: 27-39.

KRASUSKA M. \& MiścicKi S. 2002: Wielkoobszarowa charakterystyka drzewostanów Białowieskiego Parku Narodowego. [Large-scale characteristics of forest stands in Białowieski National Park.] - Sylwan 146: 73-90 [in Polish, English abstr.].

Krebs C.J. \& KenNey A.J. 2011: Ecological Methodology v. 7.2 - Program Compiled in FORTRAN LF Express 7.1 and DELPHI 2007. Dept. of Zoology, Univeristy of British Columbia, Vancouver.

KROMP B. 1999: Carabid beetles in sustainable agriculture: a review on pest control efficacy, cultivation impacts and enhancement. - Agric. Ecosys. Environ. 74: 187-228.

KwiatKowski A. 2011: Assemblages of carabid beetles (Coleoptera, Carabidae) in humid forest habitats of different stages of succession in the Puszcza Knyszyńska Forest (northern Poland). - Zookeys 100: 447-460.

Latty E.F., Werner S.M., Mladenoff D.J., Raffa K.F. \& Sickley T.A. 2006: Response of ground beetle (Carabidae) assemblages to logging history in northern hardwood-hemlock forests. - Forest Ecol. Manag. 222: 335-347.

LePš J. \& Šmilauer P. 2003: Multivariate Analysis of Ecological Data Using CANOCO. Cambridge University Press, Cambridge, $269 \mathrm{pp}$.

LÖVEI G. \& SunderLAND K.D. 1996: The ecology and behavior of ground beetles (Coleoptera: Carabidae). - Annu. Rev. Entomol. 41: 241-256.

MacArthur R.H. 1965: Patterns of diversity. - Biol. Rev. 40: 510-533.

Magura T., TóthMérész B. \& Bordan Z. 2000: Effects of nature management practice on carabid assemblages (Coleoptera, Carabidae) in a non-native plantation. - Biol. Conserv. 93: 95-102.

Magura T., Tóthmérész B. \& Elek Z. 2002: Impacts of nonnative spruce reforestation on ground beetles. - Eur. J. Soil. Biol. 38: 291-295.

Magura T., Tóthmérész B. \& Elek Z. 2003: Diversity and composition of carabids during a forest cycle. - Biodivers. Conserv. 12: 73-85.

NIEMELÄ J. 1996: Invertebrates and boreal forest management. Conserv. Biol. 11: 601-610.

Niemelä J., Haila H., Halme E., Lahti T., Pajunen T. \& Punttila P. 1988: The distribution of carabid beetles in fragments of old coniferous taiga and adjacent managed forest. - Ann. Zool. Fenn. 25: 107-119.

Niemalä J., Haila Y. \& Punttila P. 1996: The importance of small-scale heterogeneity in boreal forests: variation in diversity in forest-floor invertebrates across the succession gradient. - Ecography 18: 352-368.

Niemelä J., Koivula M. \& Kotze D.J. 2007: The effects of forestry on carabid beetles (Coleoptera: Carabidae) in boreal forests. - J. Insect Conserv. 11: 5-18.

Nietupski M., Kosewska A., Ciepielewska D. \& Sądej W. 2008: Zgrupowania Carabidae leśnego rezerwatu torfowiskowego zlokalizowanego w obrębie aglomeracji miejskiej. [Assem- 
blages of Carabidae in a forest bog reserve situated in an urban agglomeration.] - Sylwan 11: 16-25 [in Polish, English abstr.].

Ohlson M., Söderström L., Hörnberg G., Zackrisson O. \& HerMANSSON J. 1997: Habitat qualities versus long-term continuity as determinants of biodiversity in boreal old-growth swamp forests. - Biol. Conserv. 81: 221-231.

Paillet Y., Bergès L., Huältén J., Odor P., Avon C., BernhardtRömermann M., BiJlsma R.J., De Bruyn L., Fuhr M., Grandin U., Kanka R., Lundin L., Luque S., Magura T., Matesanz S., Mészáros I., Sebastià M.T., Schmidt W., Standovár T., Tóthmérész B., Uotila A., Valladares F., Vellak K. \& Virtanen R. 2010: Biodiversity differences between managed and unmanaged forests: Meta-analysis of species richness in Europe. - Conserv. Biol. 24: 101-112.

Parviainen J., Bozzano M., Estreguil C., Koskela J., Lier M., Vogt P. \& Ostapowicz K. 2007: Maintenance, conservation and appropriate enhancement of biological diversity in forest ecosystems. In Köhl M. \& Rametsteiner E. (eds): State of Europe's Forests 2007 - the MCPFE Report on Sustainable Forest Management in Europe. Ministerial Conference on the Protection of Forests in Europe, Liaison Unit, Warsaw, pp. 45-72.

Pearce J.L., Venier L.A., McKee J., Pedlar J. \& McKenney D. 2003: Influence of habitat and microhabitat on carabid (Coleoptera: Carabidae) assemblages in four stand types. - Can. Entomol. 135: 337-357.

Pettersson R.B., Ball J.P., Renhorn K.-E., Esseen P.-A. \& SjöBERG K. 1995: Invertebrate communities in boreal forest canopies as influenced by forestry and lichens with implications for passerine birds. - Biol. Conserv. 74: 57-63.

Picket S.T.A. \& White P.S. 1985: The Ecology of Natural Disturbance and Patch Dynamics. Academic Press, San Diego, 472 pp.

Pizzolotto R., Cairns W. \& Barbante C. 2013: Pilot research on testing the reliability of studies on carabid heavy metals contamination. - Baltic J. Coleopt. 13: 1-13.

SChwerk A. \& Szyszko J. 2008: Patterns of succession and conservation value of post-industrial areas in central Poland based on carabid fauna (Coleoptera: Carabidae). In Penev L., Erwin T. \& Assmann T. (eds): Back to the Roots and Back to the Future. Towards a New Synthesis between Taxonomic, Ecological and Biogeographical Approaches in Carabidology. Pensoft, Sofia, Moscow, pp. 469-481.

Schwerk A. \& Szyszko J. 2011: Model of succession in degraded areas based on carabid beetles (Coleoptera, Carabidae). In Kotze D.J., Assmann T., Noordijk J., Turin H. \& Vermeulen R. (eds): Carabid beetles as bioindicators: biogeographical, ecological and environmental studies. - ZooKeys 100: 319-332.

Sittonen J., Martikainen P., Punttila P. \& Rauh J. 2000: Coarse woody debris and stand characteristics in mature managed old-growth boreal mesic forests in southern Finland. - Forest Ecol. Manag. 128: 211-225.

SKALSKI T. \& Pospiech N. 2006: Beetles community structures under different reclamation practices. - Eur. J. Soil Biol. 42: 211-217.

Skalski T., Kramarz P., Laskowski R. \& Stone D. 2010: Ground beetle community responses to heavy metal pollution. - Baltic J. Coleopt. 10: 1-12.

Skalski T. Gargasz K. \& Laskowski R. 2011: Does mixed diffuse pollution decrease ground beetle diversity? - Baltic $J$. Coleopt. 11: 1-15.

SkŁodowski J. 2003: Carabid beetles in tree hole and decying stumps of the Białowieża Primeval Forest. - Baltic J. Coleopt. 3: 91-96.
SkŁodowsKi J. 2008: Carabids betele movements in a clear-cut area with retention groups of Trees. In Penev L., Erwin T. \& Assmann T. (eds): Back to the Roots and Back to the Future. Towards a New Synthesis between Taxonomic, Ecological and Biogeographical Approaches in Carabidology. Pensoft, Sofia, Moscow, pp. 451-467.

SkŁODOWSKI J. 2014: Effects of top-soil preparation and broadleaved tree mixture on carabid beetles in afforested fallow plots. - Restor. Ecol. 22: 13-21.

SkŁodowski J. \& GarbalińsKa P. 2011: Ground beetle (Coleoptera, Carabidae) assemblages inhabiting Scots pine stands of Puszcza Piska Forest: six-year responses to a tornado impact. —ZooKeys 100: 371-392.

Šmilauer P. 2002: WinKyst 1.0. Ceske Budejovice, available from: http://www.canodraw.com/winkyst.htm.

StańsKa M., Hajdamowicz I. \& ŻabKa M. 2002: Epigeic spiders of alder swamp forests in Eastern Poland. In Toft S. \& Schraff N. (eds): European Arachnology 2000. Proceedings of the 19th European Colloquium of Arachnology. Aarhus University Press. pp. 191-197.

StatSoft Inc. 2011: STATISTICA (Data Analysis Software System), Version 10. www.statsoft.com

SzUJECKI A. 2001: Próba szacunkowej waloryzacji lasów Puszczy Białowieskiej metodą zooindykacyjną. [The Attempt of Valorization of Białowieża Forests Using Zooindicative Method.] SGGW, Warszawa, 419 pp. [in Polish].

SzUJECKI A. 2006: Zooindication-Based of Anthropogenic Transformations in Białowieża Primeval Forest. Warsaw Agricultural university Press, Warszawa, 444 pp.

Szujecki A., Mazur S., Perliński S. \& Szyszko J. 1983: The Process of Forest Soil Macrofauna Formation after Afforestation of Farmland. SGGW-AR, Warszawa, 196 pp.

SzYSZKo J. 1983: State of Carabidae (Col.) fauna in fresh pine forest and tentative valorization of this environment. SGGW-AR, Warszawa, $80 \mathrm{pp}$

Thiele H.-U. 1977: Carabid Beetles in Their Environments - A Study on Habitat Selection by Adaptations in Physiology and Behaviour. Springer, Berlin, Heilderberg, New York, 369 pp.

Toïgo M., Paillet Y., Noblecourt T., Soldati F., Gosselin F. \& DAUFFY-Richard E. 2013: Does forest management abandonment matter more than habitat characteristics for ground beetle? - Biol. Conserv. 157: 215-224.

Turin H. 2000: De Nedrelandse loopkevers. Verspreiding en oecologie (Coleoptera: Carabidae). Nationaal Natuurhistorisch Museum Naturalis, KNNV, Uitgeverij, 666 pp. [in Dutch].

Turin H., Penev L. \& Casale A. (eds) 2003: The Genus Carabus in Europe. Fauna Europea Evertebrata, Pensoft, Sofia, Moscow, $511 \mathrm{pp}$.

Uotila A., Kouki J., Kontkanen H. \& Pulkkinen P. 2002: Assesing the naturalness of boreal forests in eastern Fennoscandia. - Forest. Ecol. Manag 161: 257-277.

Vuidot A., Paillet Y., Archaux F. \& Gosselin F. 2011: Influence of tree characteristics and forest management on tree microhabitats. - Biol. Conserv. 144: 441-450.

WesoŁowski T. \& RowiŃski P. 2006: Tree defoliation by winter moth Operopthera brumata L. during an outbreak affected by structure of forest landscape. - Forest. Ecol. Manag. 221: 299-305.

Received December 30, 2013; revised and accepted September 18, 2014 Prepublished online October 1, 2014 